\title{
Cheeses of Turkey: 3. Varieties containing herbs or spices
}

\author{
Ali A. HAYAloglu ${ }^{1 *}$, Patrick F. Fox ${ }^{2}$ \\ ${ }^{1}$ Department of Food Engineering, Engineering Faculty, Inonu University, 44280 Malatya, Turkey \\ ${ }^{2}$ Department of Food and Nutritional Sciences, University College, Cork, Ireland
}

Received 16 July 2007 - Accepted 11 October 2007

\begin{abstract}
Ripened cheese varieties containing herbs are traditional in Turkey and have been manufactured for more than 200 years in the east and southeast of the country. They are manufactured from raw milk, semi-hard in texture and salty in taste and have the aroma of garlic or thyme due to added herbs. Twenty-five types of herb, including Allium, Thymus, Silene and Ferula species which are most popular, are used individually or as appropriate mixtures. The most popular of these cheeses is Otlu which is produced mainly in the Van province of Turkey in small dairies and villages, but now is produced in other cities of the eastern region of Turkey and its popularity increases continuously throughout Turkey. The manufacturing technology, chemical, biochemical and microbiological status of Otlu cheese and the most common herbs used in its manufacture are reviewed. The possible effect of herbs used on the biochemical and microbiological characteristics of the cheeses are discussed also. In addition, some varieties of Otlu cheese and cheeses flavoured with spices (chilli pepper, black pepper, cinnamon, allspice, mint, thyme, cumin, etc.), including Carra, Surk and related cheeses, are discussed briefly.
\end{abstract}

\section{cheeses of Turkey / Otlu cheese / herbs / spice / proteolysis / microbiology}

摘要 - 土耳其干酪 3: 含有药草和香料的干酪。摘要 : 在土耳其的东部和东南部地区,生产 含有草药的传统成熟奶酪已有 200 多年的历史。这些干酪是用生鲜奶制作, 属于半硬质干 酪, 较咸, 由于添加了草药, 所以有大蒜或百里香的味道。苾、百里香、蝇子草和大茴香等 25 种草药是最常用的, 它们可以单独使用或几种混合在一起使用。其中最受欢迎的是奥特 卢干酪 (Otlu), 它最早是在土耳其 Van 省的小牧场和小村庄生产, 现在在土耳其的东部城市 也有生产, 并逐渐在全国范围内生产和销售。本文对奥特卢干酪的生产技术, 化学特性, 生 化特性和微生物学特性及制作干酪中常用的草药进行了论述。也讨论了草药对干酪的生化 特性和微生物学特征可能产生的影响。此外, 还简单介绍了奥特卢干酪的品种和用其他香 料 (如辣椒、黑胡椒、肉桂、多香果、薄荷、百里香、孜然等) 制作的干酪, 如 Carra、Surk 等。

\section{土耳其干酪 / 奥特卢干酪 / 草药 / 香料 / 蛋白水解 / 微生物学}

Résumé - Fromages de Turquie : 3. Variétés aux herbes et aux épices. Les variétés de fromages contenant des herbes sont traditionnelles en Turquie et sont produites depuis plus de 200 ans dans l'est et le sud-est du pays. Elles sont produites à partir de lait cru, ont une texture semidure et un goût salé et des arômes d'ail ou de thym apportés par les herbes ajoutées. Vingt-cinq sortes d'herbes, incluant les espèces Allium, Thymus, Silene et Ferula qui sont les plus populaires, sont utilisées individuellement ou en mélange. Le plus populaire de ces fromages est l'Otlu qui est produit principalement dans la province de Van en Turquie dans des petites laiteries et des villages, mais actuellement aussi dans d'autres villes de la région Est de la Turquie et sa popularité

* Corresponding author (通讯作者): ahayaloglu@inonu.edu.tr 
grandit continuellement dans tout le pays. La technologie de fabrication, le statut chimique, biochimique et microbiologique du fromage Otlu et les herbes les plus courantes utilisées dans sa fabrication sont présentés dans cette revue. L'effet possible des herbes utilisées sur les caractéristiques biochimiques et microbiologiques des fromages est aussi discuté. De plus, quelques variétés d'Otlu et de fromages aromatisés avec des épices (piment, poivre noir, cannelle, poivre de la Jamaïque, menthe, thym, cumin, etc.) incluant les fromages Carra, Surk et apparentés sont brièvement présentées.

fromage de Turquie / Otlu / fromage aux herbes / fromage aux épices / protéolyse / microbiologie

\section{INTRODUCTION}

Ripened cheeses containing herbs or spices may be similar to some other Turkish cheeses in terms of their manufacturing technology, such as brined varieties, but they differ from other brined cheeses due to their appearance, flavour and taste. Addition of herbs or spices has made it possible to produce speciality cheese. They are produced in a restricted area of Turkey where people with particular cultures reside, e.g., in eastern (Otlu cheeses) and southern (Carra or Surk cheeses) Turkey. Otlu-type cheeses have been produced in these areas for more than 200 years using traditional and artisanal techniques, but nowadays the cheeses are manufactured also in some dairies (in eastern or other parts of Turkey) with developed techniques, such as, the use of pasteurized milk, a starter culture, commerciallyproduced coagulants, etc. The manufacture of Otlu cheese in small dairy plants or marketing in big cities has increased its popularity and the level of production has increased gradually in recent years. However, Carra and Surk cheeses are manufactured only in Hatay province by traditional methods and are consumed only in the region where they are produced. It is believed that these cheeses are produced also in some cities of neighbouring Syria by Arabic people and it is thought that the cheeses acquire their characteristics from cultural interactions between the two nations. There is no detailed information on Carra and Surk cheeses or on the effects of adding spices on the microbiology and bio- chemistry of matured cheese. In this paper, the emphasis is mainly on Otlu cheese, but manufacturing technology, chemistry and the characteristics of other types of Otlu cheese, Carra and Surk, are discussed also.

\section{OTLU CHEESE}

Otlu cheese is a very famous brined cheese in Turkey and its popularity has been increasing gradually; it has long been produced traditionally (more than 200 years) in eastern cities, particularly in Van province. Although its production is concentrated in eastern Turkey, Otlu cheese is marketed throughout Turkey and has export potential to EU countries after industrialization of its production. The use of herbs gives Otlu cheese its characteristic appearance (Fig. 1) and aroma/flavour. The herbs are essential for the special flavour of the cheese but also extend its shelf-life. It has been shown that ethanol and methanol extracts of some herbs, including Allium vinale, Chaerophyllum macropodum and Prangos ferulacea, have antibacterial activity against Listeria monocytogenes serovars [36]. Otlu cheese is ripened in brine or in earthenware or plastic containers using a drysalting method and it has a semi-hard texture and salty taste. When dry-salting is used, the cheese is ripened underground for at least 3 months. However, this traditional production method has been replaced in dairies by brine-salting and marketed vacuum-packed in containers $[8,15]$. 


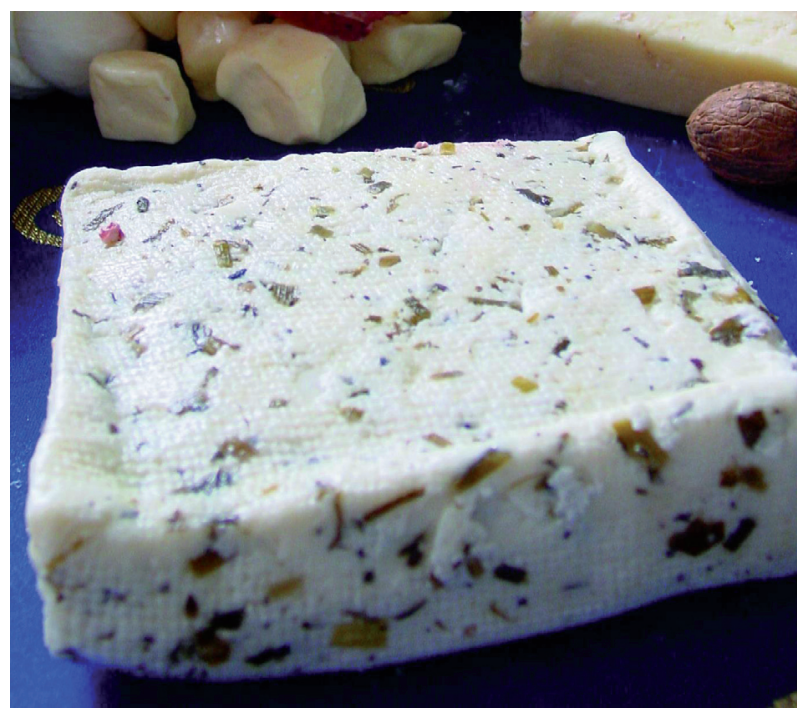

Figure 1. Otlu cheese (courtesy of U. Kamber).

\subsection{Manufacturing procedure for Otlu cheese}

\subsubsection{Cheesemaking}

In the traditional method, raw sheep's milk is used and no starter is added, but in industrial production, pasteurized milk is preferred. When pasteurized milk was used for production, the milk was acidified by a mesophilic starter cultures, e.g., Lactococcus lactis subsp. lactis plus L. lactis subsp. cremoris. If insufficient sheep's milk is available, cow's or goat's milk is added. Traditionally, home-made calf rennet is used as coagulant (see for detail Hayaloglu et al. [19]) and the clotting time ranges from 60 to $120 \mathrm{~min}$ at 30 $35^{\circ} \mathrm{C}$. After the coagulum has been cut, it is transferred to a cotton bag and the herbs are added to the curd and mixed well without whey draining. The level of herbs ranges from 0.5 to $2 \mathrm{~kg}$ to the curd obtained from $100 \mathrm{~kg}$ of milk [8, 42]. Then, the curds are pressed for 3-4 h for whey drainage and then cut into blocks about $7 \times 7 \times 2 \mathrm{~cm}$. The blocks are ripened in
$14-16 \%$ (w/v) $\mathrm{NaCl}$ brine or dry-salted. In the case of dry-salting, "lor" or "cacik" obtained by heating whey or defatted yogurt, respectively (for further information see Sects. 3.1 and 3.2), is filled into the spaces between the cheese blocks in plastic or earthenware containers. The containers filled with Otlu cheese are inverted (to promote whey drainage and to give the cheese typical aroma/flavour characteristics) and ripened underground (about $50 \mathrm{~cm}$ under the soil) for 2-3 months. In the brining method, the cheese blocks are placed in $14-16 \% \mathrm{NaCl}$ brine for $6-10 \mathrm{~h}$ and then transferred to tinned cans (preferably) and ripened in the cans for at least 1 month.

\subsubsection{Herbs used in the manufacture of Otlu cheese}

About 25 herbs are used in the manufacture of Otlu cheese, the principal of which are listed in Table I $[8,42]$. Allium is the most widely used, probably due to its abundance in the mountains or plateaus of Van province where Otlu 
Table I. Some herbs used in the manufacture of Otlu peynir ${ }^{1}$.

\begin{tabular}{ll}
\hline Latin name & Local name \\
\hline Allium & Sirmo \\
Chaerophyllum & Mendi \\
Anthriscus & Mendo \\
Silene & Siyabo \\
Thymus & Kekik, Zater \\
Mentha & Yarpuz, yabani nane \\
Ocimum & Reyhan, feslegen \\
Heracleum & Sov \\
Ferula & Heliz \\
\hline
\end{tabular}

${ }^{1}$ Adapted from Coskun [8].

cheese production is common, and because of consumer preference [8]. These herbs may be added alone to the curds or a mixture of the two or more may be used at a level of 0.5 to $2 \mathrm{~kg}$ for the curd obtained from $100 \mathrm{~kg}$ milk. The antimicrobial properties of some herbs used in the manufacture of Otlu cheese have been studied. Sagun et al. [36] showed that ethanol or methanol extracts of some herbs, including Allium vinelae, Chaerophyllum macropodum and Prangos ferulacea, exhibited activity against Listeria monocytogenes serovars. The antimicrobial effects of some herbs and their extracts on some potentially pathogenic microorganisms have also been investigated [1, 5, 23, 30-34].

However, the herbs used do not influence the activity of starter bacteria. Coskun [7], who studied the effect of Allium sp., Thymus sp. and Anthriscus sp. on the activity of Lactococcus lactis subsp. lactis and L. lactis subsp. cremoris, found no negative effect on the growth of these bacteria. Also, these herbs did not influence the growth of Streptococcus thermophilus or Lactobacillus delbrueckii subsp. bulgaricus used as adjuncts in the manufacture of Otlu cheese [4].

\subsection{Chemistry and biochemistry of Otlu cheese}

\subsubsection{Chemical composition}

The composition of Otlu cheese varies widely due to the lack of a standard manufacturing protocol. The mean composition and $\mathrm{pH}$ of the cheese are summarized in Table II. The dry matter, fat, salt and titratable acidity are higher in ripened than in unripened cheese, while the $\mathrm{pH}$ of the cheese shows the opposite trend, but the total protein content is identical in unripened and ripened cheeses [40]. Addition of herbs results in a decrease in $\mathrm{pH}$ and increasing the level of herbs in Otlu cheese significantly reduces the $\mathrm{pH}$ of the cheese [41,45]. Herbs also increase the titratable acidity in Otlu cheese, suggesting that the herbs may stimulate the growth of lactic acid bacteria present in the raw milk [10]. Demirci [11] found the concentration of $\mathrm{Ca}, \mathrm{P}, \mathrm{Na}, \mathrm{K}$ and $\mathrm{Mg}$ in Otlu cheese to be $678,416,1103,180$ and $33.4 \mathrm{mg} \cdot 100 \mathrm{~g}^{-1}$, respectively. The minerals, including $\mathrm{Ca}, \mathrm{P}, \mathrm{Na}$ and $\mathrm{Mg}$, in Otlu cheese were monitored during $90 \mathrm{~d}$ by Sagun et al. [39]; the levels of $\mathrm{Ca}$ and $\mathrm{Mg}$ decreased, while the level of $\mathrm{Na}$ increased significantly with age, but the level of $\mathrm{P}$ did not change significantly. The levels of some minor elements, including $\mathrm{Zn}, \mathrm{Cu}$, $\mathrm{Fe}$ and $\mathrm{Mn}$ in 90-d old cheeses were 33.6, $9.4,25.4$ and $3.5 \mathrm{mg} \cdot \mathrm{kg}^{-1}$, respectively. The noticeably high level of Fe in Otlu cheese [29] was thought to originate from the herbs added to the cheese curd [36]. A high level of vitamin $\mathrm{C}$ in Otlu cheese ( $3 \mathrm{mg} \cdot 100 \mathrm{~g}^{-1}$ of cheese) was reported by Coskun [8], but this is not the case for other cheese types; this may be due to the type of herbs used in its production [9].

\subsubsection{Proteolysis}

The extent of proteolysis, expressed as soluble nitrogen fractions, in Otlu cheese 
Table II. Chemical composition and $\mathrm{pH}$ of ripened and unripened samples of Otlu cheese collected in Van province (with permission of Tarakci et al. [42]).

\begin{tabular}{|c|c|c|c|c|}
\hline \multirow{2}{*}{ Variables } & \multicolumn{2}{|c|}{ Unripened cheeses $(n=20)$} & \multicolumn{2}{|c|}{ Ripened cheeses $(n=20)$} \\
\hline & Range & Mean \pm SD & Range & Mean \pm SD \\
\hline Dry matter $(\%)$ & $40.04-56.15$ & $45.80 \pm 4.46$ & $50.54-66.05$ & $55.41 \pm 4.45$ \\
\hline Fat (\%) & $14.50-24.50$ & $17.83 \pm 2.71$ & $18.50-31.50$ & $24.37 \pm 3.70$ \\
\hline Protein $(\%)$ & $16.59-26.02$ & $21.37 \pm 3.63$ & $18.01-25.98$ & $21.22 \pm 1.96$ \\
\hline Salt $(\%)$ & $3.86-6.40$ & $5.19 \pm 0.81$ & $4.80-9.07$ & $6.64 \pm 1.19$ \\
\hline $\mathrm{pH}$ & $4.90-5.96$ & $5.52 \pm 0.28$ & $4.01-5.40$ & $4.55 \pm 0.31$ \\
\hline Titratable acidity ${ }^{1}$ & $0.27-0.71$ & $0.48 \pm 0.12$ & $0.82-2.35$ & $1.84 \pm 0.37$ \\
\hline
\end{tabular}

${ }^{1}$ Expressed as g lactic acid per $100 \mathrm{~g}$ of cheese.

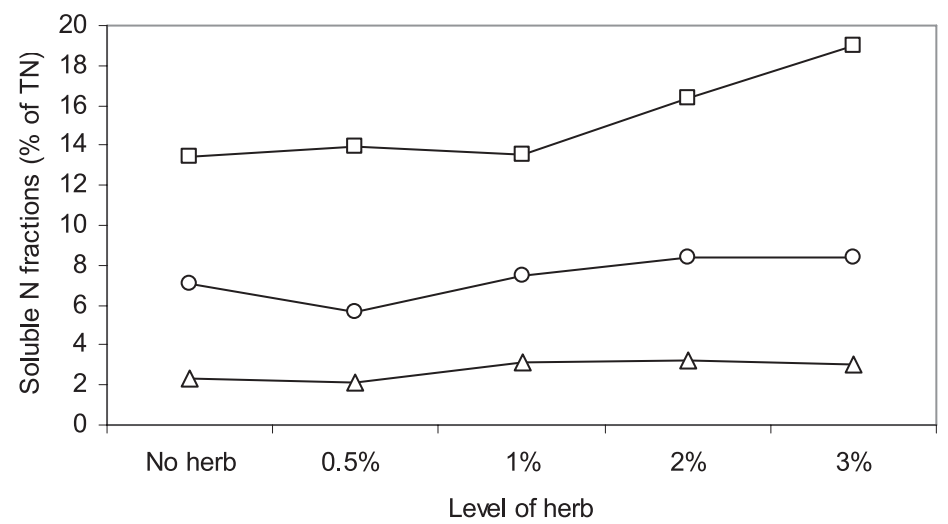

Figure 2. Effect of level of herbs used in the manufacture of Otlu cheese on the formation of watersoluble ( $\square), 12 \%$ trichloroacetic acid-soluble (o) and 5\% phosphotungstic acid-soluble $(\Delta)$ nitrogen fractions (as percentages of total nitrogen). Adapted from Coskun and Tuncturk [10].

during ripening has been studied by several workers $[6,10,43-45,47,48]$. Addition of some herbs, such as Allium [10,15], Prangos [41] or Chaerophyllum [45] enhanced proteolysis in Otlu cheese during ripening (Fig. 2). However, increasing the level of herbs caused some sensory problems in the cheese, and the best sensory scores were obtained for the cheese with $1 \%$ herb $[41,45]$. Higher levels of soluble nitrogen were found in the cheeses made from raw milk than those from pasteurized milk [6, 48]. Tuncturk and Coskun [47] reported that proteolysis indices for Otlu cheese were higher in dry-salted cheeses than in their brined counterparts probably due to migration of some nitrogenous compounds into brine. The level of watersoluble nitrogen increased in the brine of Otlu cheese during ripening [48]; this is expected, since some peptides and amino acids diffuse into the brine during ripening. Therefore, it is desirable to analyze the nitrogen fractions both in cheese and its brine during ripening in order to quantify and better understand the changes of these fractions in the cheeses ripened under brine. Proteolysis in Otlu cheese has not been studied using chromatographic methods. Most workers determined soluble nitrogen fractions by the Kjeldahl method during $90 \mathrm{~d}$ of ripening (Tab. III). To the authors' knowledge, no in-depth study on proteolysis, i.e., RP-HPLC of peptides 
and individual amino acids during ripening has not been reported. Tarakci et al. [42] determined the electrophoretic patterns of ripened and unripened Otlu cheese collected in Van province. Extensive degradation of $\alpha_{s 1}$-casein was observed in ripened Otlu cheese but $\beta$-casein remained intact, as in other bacterially-ripened cheeses.

The levels of putrescine, cadaverine, histamine, tyramine and spermidine in nine samples of Otlu cheese were monitored using HPLC by DurluOzkaya [13], who reported that tyramine is the principal amine in Otlu cheese. Yetismeyen [51], who investigated 20 samples of Otlu cheese, found a positive relationship between the formation of biogenic amines and the levels of titratable acidity, protein, water-soluble nitrogen, non-protein nitrogen and tyrosine. Durlu-Ozkaya [13] and Yetismeyen [51] reported that the concentrations of amines in Otlu cheese were much lower than the toxic levels. Histamine was detected in Otlu cheese at various concentrations, i.e., 0 to $52.5 \mathrm{mg} \cdot \mathrm{kg}^{-1}$ [13], 25.6 to $957.6 \mathrm{mg} \cdot \mathrm{kg}^{-1}$ [40] and 0.6 to $9.6 \mathrm{mg} \cdot \mathrm{kg}^{-1}$ [50]. The concentration of histamine increased during ripening from 44.6 or $21.9 \mathrm{mg} \cdot \mathrm{kg}^{-1}$ at the beginning of ripening to 147.4 or $46.2 \mathrm{mg} \cdot \mathrm{kg}^{-1}$ after $90 \mathrm{~d}$ ([15] or [37] respectively). Ekici et al. [15] claimed that these levels of histamine are not a risk to health. Histamine levels in brined herbs used in the manufacture of Otlu cheese were determined by Ekici et al. [15]; 23.8, 23.0, 24.9 and $24.2 \mathrm{mg} \cdot \mathrm{kg}^{-1}$ histamine were found in brined herbs including Allium, Ferula, Anthriscus and Silene, respectively. These levels can be considered negligible for Otlu cheese to which the herbs are added at a level of $1 \%$.

\subsubsection{Lipolysis}

Lipolysis, expressed as acid degree value (ADV), in Otlu cheese during ripen- ing has been monitored in many studies. The use of raw milk in the manufacture of Otlu cheese enhanced lipolysis, due probably to the action of indigenous milk lipase [6]. The ADV value increased with the age of the cheese and the level of herbs added (Fig. 3); the ADV value was 4.3 times higher in ripened Otlu cheese than in unripened cheeses. This trend is observed for many cheeses, but an interesting feature of Otlu cheese is that increasing the level of herbs used in its production increased the ADV value [10]. This was explained by the fact that moulds which contaminated the herbs contributed to lipolysis $[10,41]$; however, the authors failed to prove this view, which therefore, is not fully understood. The herbs affected the $\mathrm{pH}$ and titratable acidity of Otlu cheese and the ADV values may be reflected by the lower $\mathrm{pH}$ of the cheese. Fatty acids analysis by gas chromatography was performed by Diraman [12], who found that the short-chain volatile fatty acids $\left(\mathrm{C}_{4}-\mathrm{C}_{8}\right)$ and capric acid $\left(\mathrm{C}_{10}\right)$ were present in Otlu cheese at considerable levels.

\subsection{Microbiology of Otlu cheese}

Total mean microbial counts in Otlu cheese are as high as 7.1 to $9.0 \log \mathrm{cfu} \cdot \mathrm{g}^{-1}$ $[8,22,27]$ and increase with age $[6,43,47]$. The number of lactic acid bacteria increased during the first $30 \mathrm{~d}$ of ripening, then decreased to $90 \mathrm{~d}$ [6]. The low $\mathrm{pH}$ of the cheese favours the growth of nonstarter lactic acid bacteria (NSLAB). Lactobacillus species constituted the majority of NSLAB [20] and the isolates were identified as Lactobacillus plantarum (23.6\%), L. casei subsp. casei $(17.6 \%)$, L. brevis $(11.8 \%), \quad$ Pediococcus pentosaceus (17.6\%), P. acidilactici (11.8\%), Enterococcus faecalis $(11.8 \%)$ and E. faecium $(5.8 \%)$ [35]. Yeasts and moulds are present at high numbers in Otlu cheese, e.g., 7.3 [22] or 5.2 [27] $\log \mathrm{cfu} \cdot \mathrm{g}^{-1}$. The numbers 
Table III. Nitrogen fractions (as percentages of total nitrogen) in Van Otlu cheese during ripening.

\begin{tabular}{|c|c|c|c|c|c|c|c|c|c|c|c|c|}
\hline \multicolumn{4}{|c|}{$\mathrm{WSN}^{1}$} & \multicolumn{4}{|c|}{ TCA-SN $^{1}$} & \multicolumn{4}{|c|}{ PTA-SN $^{1}$} & \multirow{3}{*}{ Reference } \\
\hline 2 & 30 & 60 & 90 & 2 & 30 & 60 & 90 & 2 & 30 & 60 & 90 & \\
\hline \multicolumn{4}{|c|}{ days } & \multicolumn{4}{|c|}{ days } & \multicolumn{4}{|c|}{ days } & \\
\hline 6.1 & 10.2 & 14.1 & 15.7 & 3.4 & 4.3 & 6.6 & 9.8 & 1.9 & 3.0 & 4.2 & 3.8 & [41] \\
\hline 12.9 & 17.9 & 21.1 & 22.1 & 7.2 & 11.0 & 13.0 & 14.0 & 3.8 & 6.6 & 7.4 & 9.0 & [44] \\
\hline- & 22.7 & 25.1 & 26.5 & - & 7.5 & 8.1 & 10.2 & - & 3.6 & 5.1 & 5.0 & [43] \\
\hline 7.9 & 7.9 & 9.7 & 15.1 & 3.2 & 4.2 & 6.7 & 10.1 & 1.9 & 2.8 & 3.5 & 4.7 & [45] \\
\hline 16.1 & 20.8 & 29.3 & 24.4 & 12.0 & 13.8 & 21.1 & 17.8 & - & - & - & - & {$[50]$} \\
\hline
\end{tabular}

${ }^{1}$ WSN: water-soluble nitrogen; TCA-SN: $12 \%$ trichloroacetic acid-soluble nitrogen; PTA-SN: $5 \%$ phosphotungstic acid-soluble nitrogen.

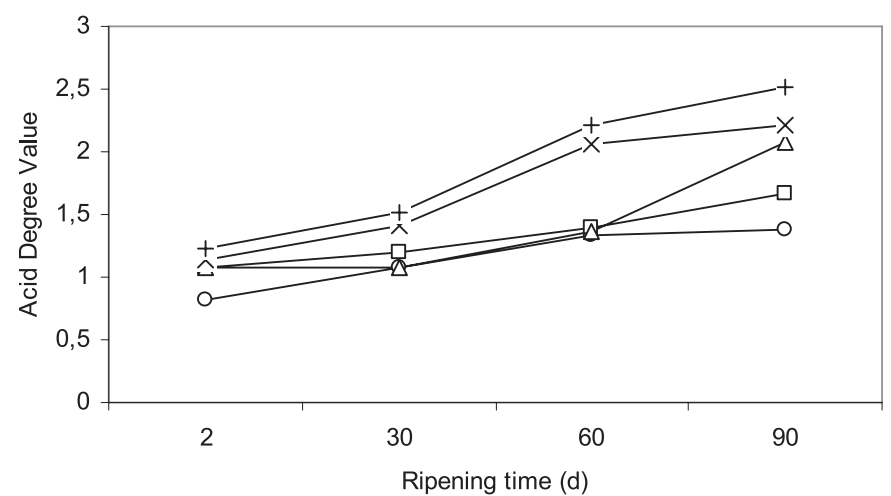

Figure 3. Effect of the level $(0 \%$ as control $(\circ), 0.5 \%(\square), 1.0 \%(\Delta), 2.0 \%(\times)$ and $3.0 \%(+))$ of herbs used in the manufacture of Otlu cheese on the release of fatty acids expressed as ADV (acid degree value). Adapted from Tarakci [41].

of yeasts and moulds decreased during ripening from 5.3 to $2.3 \log \mathrm{cfu} \cdot \mathrm{g}^{-1}$ [37] and 3.4 to $0 \log \mathrm{cfu} \cdot \mathrm{g}^{-1}[50]$; however, some fluctuations in the growth of these organisms occur during ripening [6, 47]. Counts of coliform microorganisms are high, particularly in raw milk cheeses, at the beginning of ripening, but their numbers decrease with age $[6,47,50]$. Raw milk is usually used for the production of Otlu cheese and some pathogens, including Listeria monocytogenes, Staphylococcus aureus, Escherichia coli and Salmonella spp., have been isolated from these cheeses. Sagun et al. [38], who investigated a total of 254 samples of Otlu cheese, detected Listeria spp. in
13 samples $(5.1 \%)$. Tekinsen and Ozdemir [46] examined 50 samples of unripened Otlu cheese; S. aureus (100\%) and E. coli $(62 \%)$ were isolated from the cheese at high numbers (mean values of 6.1 and $7.7 \log \mathrm{cfu} \cdot \mathrm{g}^{-1}$, respectively) and Salmonella spp. were isolated from 3 samples (6\%). Kivanc [22] reported that $30 \%$ of Otlu cheese contained $S$. aureus (range 0 to $\left.1.04 \log \mathrm{cfu} \cdot \mathrm{g}^{-1}\right)$. Erkan et al. [16], who studied 50 samples of Otlu cheese, isolated some food-borne pathogens, including Salmonella spp. (10\%), Listeria monocytogenes (8\%) and E. coli O157:H7 (4\%). They emphasized that these pathogens in the cheese may cause some health problems for consumers. 
The need to maintain proper sanitation and standardization during cheese manufacture was emphasized by Erkan et al. [16].

\section{OTHER TYPES OF OTLU CHEESE}

\subsection{Otlu Cacik}

Otlu Cacik is produced in the same areas as Otlu cheese, i.e., eastern and southeastern parts of Turkey. It is a dairy byproduct produced by heating of defatted yogurt, which is called "ayran" in Turkish. Some water is added to the yogurt during butter production; so ayran contains some additional water (probably 1:1, yogurt and water). The manufacturing steps are similar to those for Cokelek or Tomas cheeses [19], but some herbs are added to Cacik. Firstly, milk is converted to yoghurt which is churned for butter production by adding some water. After removing of milk fat, the ayran is boiled for 5-10 min or until a white coagulum floats on the surface. The coagulum is collected and transferred to a cloth for draining off the excess serum. After the curds have reached the proper level of solids, the herbs used in the manufacture of Otlu cheese are added to Cacik at a level of 1-2\% and mixed well. Cacik is consumed without ripening or used as a filler in the manufacture of Otlu cheese $[25,26]$. It has a low fat content; the chemical composition and microbiological status of Cacik are: total solids, 16.520.8\% ; fat, $1.5-4.3 \%$; protein, $8.1-13.9 \%$; salt, $0.3-3.2 \%$; pH, 3.2-4.2; WSN (as \% of TN), 4.4-9.5\%; TCA-SN, 1.8-5.8\%; total bacterial count, $2.0-4.8 \log \mathrm{cfu} \cdot \mathrm{g}^{-1}$; coliforms $<1$ and yeasts and moulds, 2.1$5.4 \log \mathrm{cfu} \cdot \mathrm{g}^{-1}$ [26].

\subsection{Otlu Lor}

This cheese is manufactured from whey by boiling and straining as for Otlu Cacik.
The curds obtained are mixed with salt (2-8\%) and herbs (2-10\%) and ripened or used as a filler in the manufacture of Otlu cheese. The mean chemical composition of Otlu Lor is: total solids, 33.7\%; fat, $7.3 \%$; protein, $17.3 \%$; salt, $5.1 \%$ and acidity, $1.5 \%[8]$.

In addition to the above cheeses, some ripened cheeses containing herbs are produced in some provinces, including Erzincan, Trabzon and Siirt. Although there is some information on the technology of these cheeses [21,49], no published data are available on their chemistry, microbiology or other characteristics.

\section{CHEESES CONTAINING SPICES}

\subsection{Surk cheese}

The name "Surk" means fat-free cheese in Arabic and "cokelek" in Turkish. Surk cheese is produced in the Hatay region of southern Turkey by traditional methods in small dairies or in villages. Surk is produced by heating defatted yogurt, named "ayran" in Turkish, at boiling temperature for about $30 \mathrm{~min}$. The proteins are precipitated by acid-heating effects and the precipitate obtained is used for the manufacture of Surk cheese. The precipitate is pressed with some weights for 5-6 h to remove excess whey and mixed well with some spices, including peppermint, thyme, mint, cumin, black pepper, cinnamon, ginger $(0.1-0.3 \%$ each), chilli pepper $(2 \%)$ and sometimes garlic (1\%). After kneading with added salt (5\%), the mixture is made into a conical shape (like a strawberry), weighing 150-200 $\mathrm{g}$ and 5 to $7 \mathrm{~cm}$ in diameter (Fig. 4). The shaped pieces are air-dried while shaded from the sun and then are either consumed fresh or wrapped in parchment paper and placed in a jar for about $30 \mathrm{~d}$ at room temperature to promote mould growth. The cheese is either 


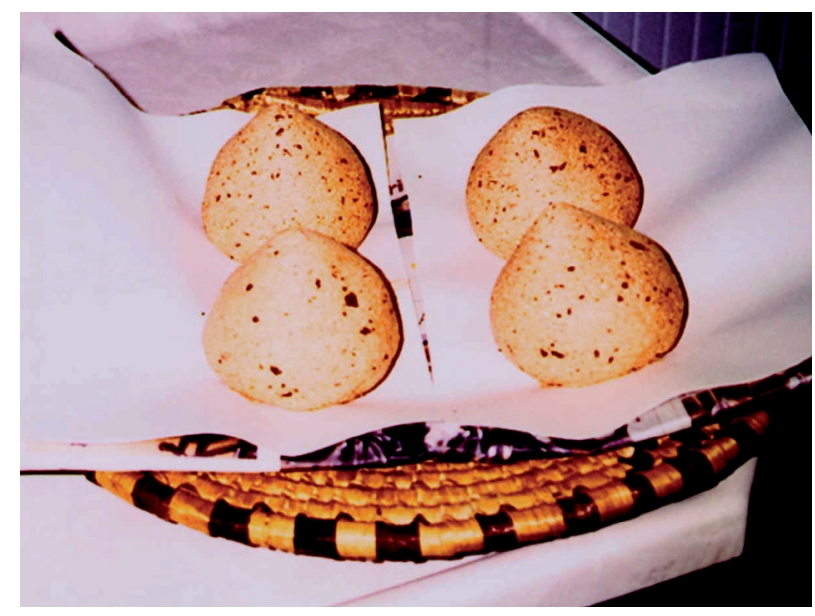

Figure 4. Surk cheese (courtesy of M.B. Guler-Akin).

immersed in olive oil and removed later or, simply, coated (smeared) with olive oil and, then, wrapped in stretch film $[3,17$, $21,28]$. When the cheese balls are kept in olive oil, the mould growth and the loss of moisture are prevented and no significant changes in the chemical composition were seen during $30 \mathrm{~d}$ of ripening [28]. Due to absence of a standard manufacturing protocol for Surk cheese, there is a significant variation in the chemical composition of this cheese (Tab. IV).

\subsection{Carra cheese}

Carra or Testi (earthenware jug in Turkish) cheese is produced traditionally from goats' milk in Hatay, southern Turkey. It has a semi-hard or hard texture and a spicy flavour due to some spices added to the curd. For the manufacture of Carra, goats' milk is warmed to $30-32{ }^{\circ} \mathrm{C}$ and coagulated by rennet within $60 \mathrm{~min}$. After cutting the coagulum into small pieces, the curds are pressed with weights for $30 \mathrm{~min}$. Then, the block of curd is sliced into pieces about $4-5 \mathrm{~cm}$ and coarse salt is sprinkled between the slices and held for 2-3 days. Salted (at 4\%) cokelek, which is a low-fat cheese produced from ayran (see Hayaloglu et al. [19]), is pressed to expel excess whey and then mixed with dried black cumin and thyme at a level of $5 \%$ each. After kneading well, the curds and cokelek are placed as layers in earthenware jugs which are covered with a piece of cloth and sealed with a mixture of wood ash, salt, olive oil and water and after this mixture has been dried it is covered tightly with another piece of cloth. Then, the jug is buried underground (about $1.5 \mathrm{~m}$ deep) to ripen for at least 4-5 months. The manufacturing protocol for Carra is not yet standardized and the production method may vary [2]. Detailed information on industrial technology and complete characterization (chemical, biochemical and microbiological aspects) of Carra cheese are lacking, but a few studies were reported recently. The mean chemical composition of 30 samples of Carra cheese were: moisture, 46.6\%; fat, $24.9 \%$; protein, $18.9 \%$; salt, $8.8 \%$; pH, 5.6 ; WSN (as \% of TN), $21.8 \%$; TCA-SN, $15.1 \%$ and proteose-peptone N, $9.2 \%$ [24]. Due to the lack of a standard manufacturing procedure for this cheese, there may be significant variations in its chemical composition. The microbial status of 50 samples of Carra cheese collected 
Table IV. Chemical composition and $\mathrm{pH}$ of Surk cheese.

\begin{tabular}{|c|c|c|c|c|}
\hline \multirow[t]{2}{*}{ Variables } & \multicolumn{2}{|c|}{$\begin{array}{l}\text { Guler-Akin, Konar }[18] \\
\qquad(n=36)\end{array}$} & \multicolumn{2}{|c|}{$\begin{array}{l}\text { Durmaz et al. [14] } \\
\quad(n=25)\end{array}$} \\
\hline & Range & Mean & Range & Mean \\
\hline Dry matter (\%) & $36.7-55.2$ & 44.3 & $36.7-65.3$ & 49.8 \\
\hline Fat $(\%)$ & $3.1-22.4$ & 9.0 & $3.0-25.5$ & 14.7 \\
\hline Fat-in-dry matter & $8.0-27.7$ & 19.62 & $8.2-46.8$ & 29.0 \\
\hline Protein $(\%)$ & $9.5-28.1$ & 19.0 & $18.3-38.9$ & 26.4 \\
\hline Salt $(\%)$ & $4.5-13.0$ & 8.4 & $2.5-7.9$ & 5.4 \\
\hline $\mathrm{pH}$ & $4.0-6.3$ & 4.94 & $4.5-8.0$ & 5.8 \\
\hline Titratable acidity ${ }^{1}$ & $0.5-2.8$ & 1.1 & $0.4-3.2$ & 1.4 \\
\hline WSN (as \% of TN) & - & - & $9.5-47.7$ & 31.7 \\
\hline
\end{tabular}

${ }^{1}$ Expressed as g lactic acid per $100 \mathrm{~g}$ of cheese.

from retail markets in the Hatay region were $\left(\log \mathrm{cfu} \cdot \mathrm{g}^{-1}\right)$ : total mesophilic bacteria, 8.27; Staphylococcus aureus, 3.4; enterococci, 5.64; Enterobacteriaceae, 5.75; coliforms, 4.0; E. coli, 3.63; yeasts and moulds, 7.68 [2]. The use of raw milk and the absence of a starter in the manufacture of the cheese and poor hygienic conditions during its manufacture, ripening and marketing (under un-refrigerated conditions) favour the presence and survival of pathogens.

\section{CONCLUDING REMARKS}

Ripened cheeses containing herbs or spices are scarce in the world but these types of cheese have been traditionally manufactured and consumed for many years in Turkey. Recent studies on Otlu cheese have increased interest on this type of cheese, but data are not sufficient. Further research is needed to understand the effects of herbs on primary and secondary proteolysis and volatile aroma compounds. Furthermore, no detailed studies have been made on Surk and Carra cheeses, which have a unique taste and flavour and should be saved for future generations for cultural and socio-economical reasons.

There are several variants of cheese containing herbs or spices and ripened in oval earthenware containers. Their manufacturing protocols are generally like Tulum cheese but with some differences. These cheeses are filled into earthenware containers instead of goat-skin bags and are ripened by burying underground (about $50 \mathrm{~cm}$ under the soil) for more than 3 months. Skim milk or partially-skimmed milk, cow's, sheep's or goat's or their unknown mixtures are used for their manufacture. It should be noted that the chemical and biochemical characteristics of these cheese are different from Tulum cheese and they are distinguishable by sensory tests. The cheeses ripened in earthenware containers and their production areas (in parenthesis) are Canak (Yozgat), Comlek (Kayseri, Cankiri, Nevsehir, Kirsehir), Kup (Nigde, Sivas, Bitlis, Isparta, Trabzon, Artvin, Tokat), Ayas (Ankara) and Kupecik (Cankiri) cheeses [21,49]. These cheeses have been manufactured in these cities and their rural areas for domestic or home consumption. They were not marketed regularly in other cities and they are manufactured by centuries-old procedures. Undoubtedly, improving their production technology, while maintaining the basic manufacturing steps, may improve the quality of these cheeses, increase their market share and create new jobs for local inhabitants. 
Acknowledgements: The authors thank Dr. Y. Tuncturk (Yuzuncu Yil University, Van, Turkey) for his critics and valuable comments on Otlu cheese section of the manuscript.

\section{REFERENCES}

[1] Akgul A., Kivanc M., Inhibitory effects of six Turkish thyme-like spices on some common food-borne bacteria, Nahrung 32 (1988) 201-203.

[2] Aygun O., Aslantas O., Oner S., A survey on the microbiological quality of Carra, a traditional Turkish cheese, J. Food Eng. 66 (2005) 401-404.

[3] Aygun O., Yaman M., Durmaz H., A survey on occurrence of Tyrophagus putrescentiae (Acari: Acaridae) in Surk, a traditional Turkish dairy product, J. Food Eng. 78 (2007) 878-881.

[4] Bakirci I., The effects of some herbs on the activities of thermophilic dairy cultures, Nahrung 43 (1999) 333-335.

[5] Baydar H., Sagdic O., Ozkan G., Karadogan T., Antibacterial activity and composition of essential oils from Origanum, Thymbra and Satureja species with commercial importance in Turkey, Food Control 15 (2003) 169-172.

[6] Coskun H., Microbiological and biochemical changes in Herby cheese during ripening, Nahrung 42 (1998) 309-313.

[7] Coskun H., Otlu peynir yapiminda kullanilan bazi otlarin mezofilik starter kulturlerin aktivitesi uzerine etkisi, in: Gida Muhendisligi Sergisi ve Kongresi, Gaziantep Universitesi, 16-18 September, Gazinatep, Turkey, 1998, pp. 39-46.

[8] Coskun H., Otlu peynir, Gida Teknolojisi Dernegi Yayinlari, No. 31, Ankara, Turkey, 2005.

[9] Coskun H., Ozturk B., Vitamin C contents of some herbs used in Van herby cheese (Van Otlu peynir), Nahrung 44 (2000) 379-380.

[10] Coskun H., Tuncturk Y., The effect of Allium sp. on the extension of lipolysis and proteolysis in Van herby cheese during maturation, Nahrung 44 (2000) 52-55.

[11] Demirci M., Ulkemizin onemli peynir cesitlerinin mineral madde duzeyi ve enerji degerleri, Gida 13 (1988) 17-21.

[12] Diraman H., Izmir ilinde satilan bazi Turk sut urunlerindeki yag asitlerinin cis-trans izomerleri ve konjuge linoleik asit duzeylerinin kapiler gaz kromatografik yontem ile belirlenmesi uzerine bir calisma, Gida 29 (2004) 381-389.

[13] Durlu-Ozkaya F., Biogenic amine content of some Turkish cheeses, J. Food Process. Preserv. 26 (2002) 259-265.

[14] Durmaz H., Tarakci Z., Sagun E., Aygun O., Surkun kimyasal ve duyusal nitelikleri, Firat Universitesi Saglik Bilimleri Dergisi 18 (2004) 85-90.

[15] Ekici K., Coskun H., Tarakci Z., Ondul E., Sekeroglu R., The contribution of herbs to the accumulation of histamine in "Otlu" cheese, J. Food Biochem. 30 (2006) 362371 .

[16] Erkan E.M., Ciftcioglu G., Vural A., Aksu H., Some microbiological characteristics of herbed cheeses, J. Food Qual. 30 (2007) 228-236.

[17] Guler M.B., Surk uretiminde kullanilan katki maddeleri, in: Demirci M. (Ed.), Sut mikrobiyolojisi ve katki maddeleri, Rebel Yayincilik, Istanbul, Turkey, 2000, pp. 443449.

[18] Guler-Akin M.B., Konar A., Antakya piyasasinda satilan Surklerin bazi özellikleri, Harran Universitesi Ziraat Fakultesi Dergisi 6 (2002) 55-63.

[19] Hayaloglu A.A., Fox P.F., Guven M., Cakmakci S., Cheeses of Turkey: 1. Varieties ripened in goat-skin bags, Lait 87 (2007) 7995.

[20] Isleyici O., Alyuz N., Van ilinde satisa sunulan Otlu peynirlerde mikrofloranin ve laktik asit bakterilerinin turlerinin belirlenmesi, in: Demirci M. (Ed.), Sut mikrobiyolojisi ve katki maddeleri, Rebel Yayincilik, Istanbul, Turkey, 2000, pp. 540-545.

[21] Kamber U., Geleneksel Anadolu Peynirleri, Miki Matbaacilik, Ankara, Turkey, 2005.

[22] Kivanc M., A survey on the microbiological quality of various cheeses in Turkey, Int. J. Food Microbiol. 9 (1989) 73-77.

[23] Kivanc M., Akgul A., Inhibitory effects of spice essential oils on yeasts, Tr. J. Agric. Forest. 13 (1989) 68-69.

[24] Konar A., Guler M.B., Hatay Carra (Testi) peyniri yapimi, kimyasal bilesimleri ve proteoliz duzeyleri, in: 5. Sut ve sut urunleri sempozyumu, Trakya University, 2122 May, Tekirdag, Turkey, 1998, pp. 145153.

[25] Kucukoner E., Tarakci Z., Van ve yoresinde uretilen Cacigin (Otlu cokelek) bazi ozelliklerinin arastirilmasi, in: 5. Sut ve sut 
urunleri sempozyumu, Trakya University, 21-22 May, Tekirdag, Turkey, 1998, pp. 175-184.

[26] Kucukoner E., Tarakci Z., Sagdic O., Physicochemical and microbiological characteristics and mineral content of herby cacik, a traditional Turkish dairy product, J. Sci. Food Agric. 86 (2006) 333-338.

[27] Kurt A., Akyuz N., Van otlu peynirinin yapilisi ve mikrobiyolojik, fiziksel ve kimyasal nitelikleri, Gida 9 (1984) 141-146.

[28] Masatcioglu T.M., Avsar Y.K., Effects of flavorings, storage condition, and storage time on survival of Staphylococcus aureus in Surk cheese, J. Food Prot. 68 (2005) 1487-1491.

[29] Mendil D., Mineral and trace metal levels in some cheese collected from Turkey, Food Chem. 96 (2006) 532-537.

[30] Ozkan G., Sagdic O., Ozcan M., Inhibition of pathogenic bacteria by essential oils at different concentrations, Food Sci. Technol. Int. 9 (2003) 85-88.

[31] Ozkan G., Sagdic O., Ozcan M., Ozcelik H., Unver A., Antioxidant and antibacterial activities of Turkish endemic Sideritis extracts, Grasas Aceites 55 (2005) 8-11.

[32] Sagdic O., Sensitivity of four pathogenic bacteria to Turkish thyme and oregano hydrosols, Lebensm.-Wiss. u. Technol. 36 (2003) 467-473.

[33] Sagdic O., Kuscu A., Ozcan M., Ozcelik S., Effects of Turkish spice extracts at various concentrations on the growth of Escherichia coli O157:H7, Food Microbiol. 19 (2002) 473-480.

[34] Sagdic O., Ozcan M., Antibacterial activity of Turkish spice hydrosols, Food Control 14 (2003) 141-143.

[35] Sagdic O., Simsek B., Kucukoner E., Microbiological and physicochemical characteristics of Van herby cheese, a traditional Turkish dairy product, Milchwissenschaft 58 (2003) 382-385.

[36] Sagun E., Durmaz H., Tarakci Z., Sagdic O., Antibacterial activities of the extracts of some herbs used in Turkish Herby cheese against Listeria monocytogenes serovars, Int. J. Food Prop. 9 (2006) 255-260.

[37] Sagun E., Ekici K., Durmaz H., The formation of histamine in herby cheese during ripening, J. Food Qual. 28 (2005) 171-178.

[38] Sagun E., Sancak Y.C., Isleyici O., Ekici K., Van ve cevresi sut ve otlu peynirlerinde Listeria turlerinin varligi ve yayginligi uzerinde bir arastirma, Tr. J. Vet. Anim. Sci. 25 (2001) 15-19.
[39] Sagun E., Tarakci Z., Sancak H., Durmaz H., Salamura Otlu peynirde olgunlasma suresince mineral madde degisimi, Yuzuncu Yil Universitesi Veteriner Fakultesi Dergisi 16 (2005) 21-25.

[40] Sancak Y.C., Ekici K., Isleyici O., Sekeroglu R., Noyan T., Histamine levels in herby cheese, in: Proceedings International Dairy Symposium, Suleyman Demirel University, 24-28 May, Isparta Turkey, 2004, pp. 117119.

[41] Tarakci Z., The influence of helis (Prangos sp.) on characteristics of vacuum-packed Van herby cheese during ripening, Milchwissenschaft 59 (2004) 619-623.

[42] Tarakci Z., Coskun H., Tuncturk Y., Some properties of fresh and ripened herby cheese, a traditional variety produced in Turkey, Food Technol. Biotechnol. 42 (2004) 47-50.

[43] Tarakci Z., Durmaz H., Sagun E., Sancak H., Influence of brine concentration on chemical, microbiological and sensory characteristics of herby cheese, Indian Vet. J. 82 (2005) 279-282.

[44] Tarakci Z., Kucukoner E., Effect of different cultures on physico-chemical and sensory properties of low-fat Herby cheese, Food Sci. Technol. Int. 12 (2006) 423-428.

[45] Tarakci Z., Sagun E., Durmaz H., The effect of mendi (Chaerophyllum sp.) on ripening of vacuum-packed herby cheese, Int. J. Dairy Technol. 59 (2006) 35-39.

[46] Tekinsen K.K., Ozdemir Z., Prevalence of foodborne pathogens in Turkish Van Otlu (herb) cheese, Food Control 17 (2006) 707711.

[47] Tuncturk Y., Coskun H., The effect of production and ripening methods on some properties of the herby cheese, Otlu peynir, Milchwissenschaft 57 (2002) 638-640.

[48] Tuncturk Y., Coskun H., Ghosh B.C., Nitrogen fractions in brine during ripening of herby cheese (Otlu peynir), Indian J. Dairy Sci. 56 (2003) 208-212.

[49] Unsal A., Sut uyuyunca-Turkiye peynirleri, Yapi Kredi Yayinlari, Istanbul, Turkey, 2003.

[50] Yetismeyen A., Otlu peynir uretim tekniginin ve kalite ozelliklerinin gelistirilmesi uzerine bir arastirma, Tr. J. Agric. Forest. 21 (1997) 237-241.

[51] Yetismeyen A., Bazi geleneksel peynirlerimizin biyojen amin iceriginin saptanmasi ve peynirlerin mikrobiyolojik, kimyasal ozellikleriyle olan iliskisinin arastirilmasi, Ankara University Scientific Research Project Report, Ankara, Turkey, 2005. 